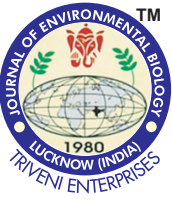

DOI : http://doi.org/10.22438/jeb/39/6/MRN-463
ISSN: 0254-8704 (Print) ISSN: 2394-0379 (Online) CODEN: JEBIDP

\title{
Application of Azotobacter, Vesicular Arbuscular Mycorrhiza and Phosphate Solubilizing Bacteria for potato cultivation in Central Plain Zone (Pb-3) of Punjab
}

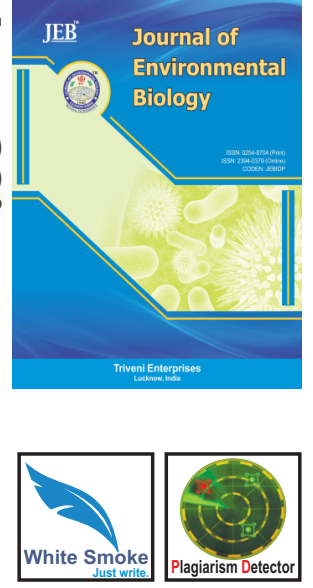

\section{Authors Info}

I. Lallawmkima', S.K. Singh ${ }^{2 *}$ and M. Sharma ${ }^{3}$

'Department of Agronomy, Lovely Professional University, Phagwara-144 411, India

${ }^{2}$ Department of Horticulture, Lovely Professional University,

Phagwara-144 411, India

${ }^{3}$ Department of Vegetable Science, Punjab Agricultural University, Ludhiana-141 004, India

${ }^{*}$ Corresponding Author Email shailesh.19105@lpu.co.in

Key words

Azobacter Benefit : Cost ratio Phosphate solubilizing bacteria Solanum tuberosum Vesicular arbuscular mycorrhiza

Publication Info

Paper received : 15.09 .2016 Revised received : 18.04 .2017 Re-revised received : 01.12.2017 Accepted : 02.01 .2018

\section{Abstract}

Aim : Potato (Solanum tuberosum) is a fertilizer intensive tuber crop which responds well to bio-fertilizer towards high economic yield. The experiment was conducted to evaluate the economics of biofertilizers like Azotobacter,Vesicular Arbuscular Mycorrhiza (VAM) and Phosphate Solubilizing Bacteria (PSB) application for potato cultivation in Central Plain Zone (Pb-3) of Punjab.

Methodology : The recommended dose of $\mathrm{N}_{1} \mathrm{P}_{2} \mathrm{O}_{5}$ and $\mathrm{K}_{2} \mathrm{O}\left(120: 80: 80 \mathrm{Kg} \mathrm{ha}^{-1}\right)$ was applied as per treatments. Soil application of VAM $\left(150 \mathrm{Kg} \mathrm{ha}^{-1}\right)$, Azotobacter ( $\left.150 \mathrm{Kg} \mathrm{ha}^{-1}\right), \mathrm{PSB}\left(75 \mathrm{Kg} \mathrm{ha}^{-1}\right)$ and mustard cake $\left(5 \mathrm{qha}^{-1}\right)$ was done as basal dose. Intercultural practices were carried out as per recommendation and observations were recorded on vegetative growth, leaf area index harvesting index, yield of tubers, economic attributes and benefit cost ratio. Duncan's New Multiple Range Test was applied for statistical analysis of observations.

Results : Among all treatments, $T_{8}(50 \%$ of RDF + PSB+ Azotobacter+ VAM+ Mustard cake)and $\mathrm{T}_{6}(50 \%$ of RDF + $\mathrm{PSB}+\mathrm{VAM}+$ Azotobacter) were reported to promote better survival (98.44\% and $97.91 \%$, respectively), plant growth (181.31\% and $179.18 \%$, respectively), LeafArea Index (7.04 and 7.06, respectively), Harvesting Index (0.828 and 0.775 , respectively) and marketable yield ( 30.63 and 30.21 tonnes ha ${ }^{-1}$, respectively). The highest benefit cost ratio (1.585:1) was reported in $T_{6}$ followed by $T_{8}(1.342: 1)$.

Interpretation : Biofertilizers like PSB, VAM and Azotobacter have capacity to improve resource utilization efficiency so these inputs can be used to reduce consumption of inorganic fertilizers by $50 \%$, improve economic yield by 17.02 to $86.88 \%$ and double the farm income.

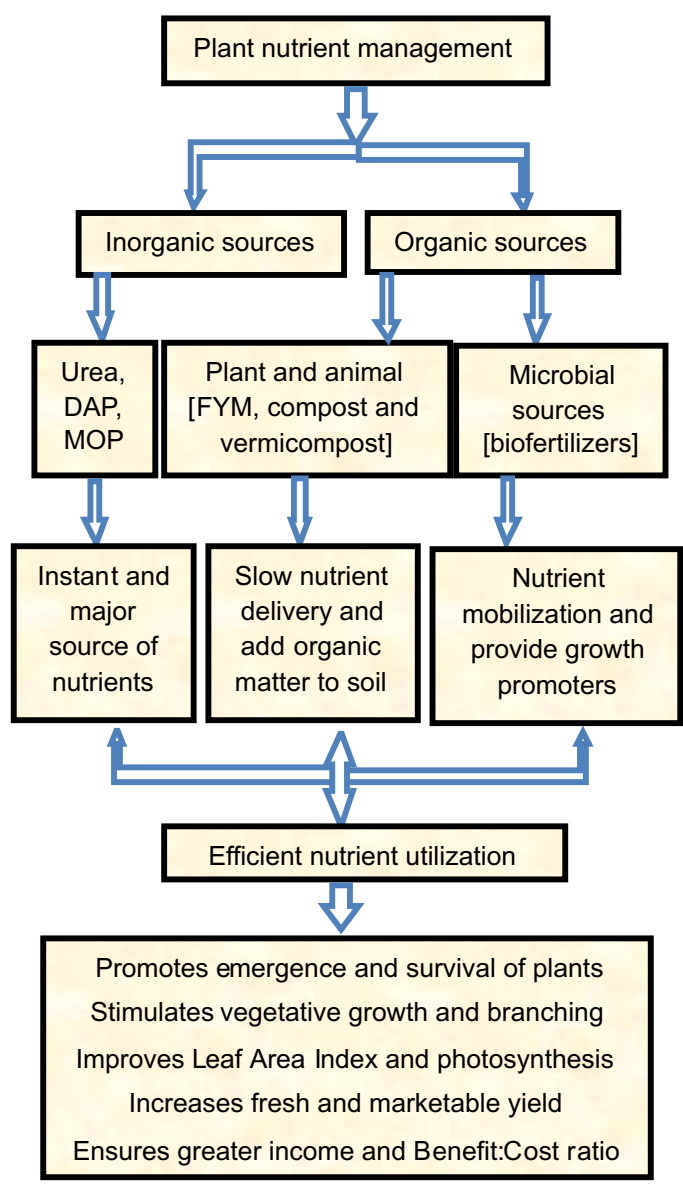




\section{Introduction}

Potato (Solanum tuberosum) is commercially grown throughout the tropics, subtropics and temperate region of the world. Potato tubers have high nutritional value, energy content and very high economic advantages which will be suitable for developing economy (Van Gijssel, 2005; Mc Gregor, 2007). India ranks third position in production of potatoes following China and Russia and accounts of 48009 thousand MT to area of 2076 thousand hectares and productivity 23.125 MT per hectare during year 2014-15 (NHB, 2017). Potato crop has high nutrient requirement as nearly $100 \mathrm{~kg} \mathrm{~N}^{-1}{ }^{-1}$ and $20 \mathrm{~kg} \mathrm{P}^{-1} \mathrm{C}^{-1}$ is being used from soil for yielding 25-30 tha-1 of tubers (Dash and Jena, 2015). Plants mostly take nitrogen in the form of nitrate and utilize them for synthesis of nucleic acids, proteins, chlorophyll and many nitrogen containing compounds (Almodares et al., 2008). Potassium is a major cation in phloem and has been reported to promote phloem transport of photosynthates (Lemoine, 2013). Excess application of nitrogen not only damages the crop quality and environment but also represents unnecessary economic expenditure of the farmers.

The high cost of chemical fertilizers along with the related ecological and health hazards necessitate finding out the alternate nutrient sources to sustain the crop yield without any adverse effect on environment. Application of organic materials like compost and biofertilizers can add and compensate the nutrient loss from soil. These organic materials will also help to restore, maintain and improve soil fertility to increase production in the given set of soil and climate. Bio fertilizers such as Azotobacter and phospho bacteria (PSB) have been recognized as important inputs for improving soil health and fertility for sustainability in crop production (Mohammadi and Sohrabi, 2012).

Biofertilizer contains living cells of various microbes that have the ability to make the nutrients available to the plant through solubilisation of unavailable nutrients like phosphorus and potassium or fixation of atmospheric minerals like nitrogen. Application of biofertilizer reduces consumption of inorganic fertilizers by 20 - $50 \%$ and can improve the crop yield by $10-20 \%$ (Mirshekari and Alipour, 2013). Microbial biomass, present in biofertilizers, add organic matter to soil so can improve soil fertility (de Araújoet. al., 2014) and can be better option than FYM for improving potato tuber yield (Narayan et al., 2013). Considering the positive impact of nutrients to enhance the yield and negative impact of inorganic sources (chemical fertilizers) over the soil and plant health, the present study focus on biofertilizers application in combination with chemical fertilizers to improve the growth and yield of potato in Central Plain Zone (Pb-3) of Punjab.

\section{Materials and Methods}

A field experiment was conducted during the year 201516 at the Agricultural Research Farm of Lovely Professional University, Jalandhar, Punjab (India). The experimental site is characterized as "Central Plain Zone (PB-3)" of Punjab and is located at $31^{\circ} 15^{\prime} \mathrm{N}$ latitude and $75^{\circ} 41^{\prime} \mathrm{E}$ longitudes at an elevation of $245 \mathrm{~m}$ above mean sea level. The whole experimental area $\left(500 \mathrm{~m}^{2}\right)$ was divided into 24 plots, each with area of $20 \mathrm{~m}^{2}$. The treatments used were $\mathrm{T}_{1}[100 \% \mathrm{RDF}(160 \mathrm{Kg}$ of $\mathrm{N}, 80 \mathrm{Kg}$ of $\mathrm{P}_{2} \mathrm{O}_{5}$ and $80 \mathrm{Kg}$ of $\mathrm{K}_{2} \mathrm{O}$ per hectare)-Recommended Dose of Fertilizers], $\mathrm{T}_{2}[50 \%$ of RDF + PSB (Phosphate Solubilizing Bacteria) + VAM (Vesicular Arbuscular Mycorrhiza)], $\mathrm{T}_{3}\left[50 \%\right.$ of RDF + PSB + Mustard cake], $\mathrm{T}_{4}[50 \%$ of RDF + PSB+ Azotobacter], $\mathrm{T}_{5}[50 \%$ of RDF + PSB + VAM + Mustard cake $], \mathrm{T}_{6}$ $[50 \%$ of RDF $+\mathrm{PSB}+\mathrm{VAM}+$ Azotobacter $], \mathrm{T}_{7}[50 \%$ of RDF + $\mathrm{PSB}+$ Azotobacter+ Mustard cake] and $\mathrm{T}_{8}[50 \%$ of RDF $+\mathrm{PSB}+$ Azotobacter+ VAM + Mustard cake]. Soil application of VAM (150 $\left.\mathrm{Kg} \mathrm{ha}^{-1}\right)$, Azotobacter (150 Kg ha $\left.{ }^{-1}\right)$, PSB $\left(75 \mathrm{Kg} \mathrm{ha}^{-1}\right)$ and Mustard cake ( $\left.5 \mathrm{q} \mathrm{ha} \mathrm{a}^{-1}\right)$ was done at the time of sowing. Sprouted tubers of Kufri Jyoti variety having uniform weight( $30-40 \mathrm{~g})$ were planted on $22^{\text {nd }}$ October 2015 at spacing of $25 \times 60 \mathrm{~cm}$ and earthing-up was done to make ridges.

Table 1 : Plant growth related attributes of potato after different treatment schedule of biofertilizers

\begin{tabular}{|c|c|c|c|c|c|c|}
\hline \multirow[t]{2}{*}{ Treatments } & \multicolumn{2}{|c|}{ After 30 days of emergence } & \multicolumn{2}{|c|}{ After 45 days of emergence } & \multicolumn{2}{|c|}{ After 60 days of emergence } \\
\hline & $\begin{array}{l}\text { Plant height } \\
\text { (cm) }\end{array}$ & $\begin{array}{l}\text { Number of } \\
\text { branches }\end{array}$ & $\begin{array}{l}\text { Plant height } \\
\text { (cm) }\end{array}$ & $\begin{array}{l}\text { Number of } \\
\text { branches }\end{array}$ & $\begin{array}{l}\text { Plant height } \\
\text { (cm) }\end{array}$ & $\begin{array}{l}\text { Number of } \\
\text { branches }\end{array}$ \\
\hline $\mathrm{T}_{1}$ & 14.86 & 3.200 & 23.20 & 3.800 & 30.07 & 4.500 \\
\hline $\mathrm{T}_{2}$ & 12.80 & 3.133 & 22.23 & 4.500 & 34.33 & 5.066 \\
\hline $\mathrm{T}_{3}$ & 12.20 & 2.733 & 21.07 & 4.000 & 27.67 & 4.800 \\
\hline $\mathrm{T}_{4}$ & 14.13 & 2.866 & 22.87 & 4.500 & 33.20 & 5.100 \\
\hline $\mathrm{T}_{5}$ & 13.73 & 3.400 & 23.37 & 4.800 & 35.33 & 5.516 \\
\hline $\mathrm{T}_{6}$ & 10.73 & 3.666 & 18.80 & 5.466 & 29.90 & 5.100 \\
\hline $\mathrm{T}_{7}$ & 11.00 & 3.533 & 19.07 & 4.566 & 29.27 & 6.333 \\
\hline $\mathrm{T}_{8}$ & 12.60 & 3.000 & 22.37 & 5.033 & 35.40 & 6.133 \\
\hline Mean & 12.76 & 3.191 & 21.62 & 4.583 & 31.90 & 5.458 \\
\hline CD at $5 \%$ & NS & 0.192 & NS & 0.191 & NS & 0.261 \\
\hline SEm \pm & 2.331 & 0.012 & 6.157 & 0.011 & 11.814 & 0.022 \\
\hline $\mathrm{CV}$ & 11.97 & 3.45 & 11.48 & 2.38 & 10.78 & 2.74 \\
\hline
\end{tabular}


The number of days taken for complete emergence was counted from date of sowing and survival percent was calculated as per the number of plants survived after 60 days of complete emergence. The plant height and number of branches (primary and secondary) of all randomly selected plants was measured at 30,45 and 60 days from the date of complete emergence.

The Leaf Area Index (LAI) of potato plant was determined after 60 days of planting as the ratio of total area of leaves to the area occupied by plants. Harvest index $(\mathrm{HI})$ was calculated by dividing the dry matter of tubers obtained on a particular harvest date by the total plant dry weight (Mazurczyk et. al., 2009). Average fresh and marketable weight of tubers in g per plant was determined with the help of weighing machine and was calculated to determine yield as $\mathrm{kg}$ per plot and tonnes per hectare.

The cost of cultivation of crop was calculated separately for each treatments by adding the value of each inputs, labour charges, irrigation charges and intercultural operations practiced during the crop season. The yield of each potato produce were converted into gross income based on the prevalent market price. The net income was calculated by deducting the cost of cultivation from the gross income obtained from each treatment. All were expressed in rupees per hectare. The Benefit Cost ratio (B: cratio) was calculated by dividing the total gross income by respective cost of cultivation.

\section{Results and Discussion}

The observations recorded on vegetative growth of potato plant include emergence, survival, plant height and number of branches. The data presented in Fig. 1 confirms that all the treatments, where bio fertilizers were applied, showed significant improvement in emergence and survival of plants. The plants of $\mathrm{T}_{8}(50 \%$ of RDF + PSB + Azotobacter+ VAM+ Mustard cake) took least (18.33) number of days for complete emergence with highest $(98.44 \%)$ survival, followed by $T_{6}$ (20 days and $97.91 \%$, respectively) and $\mathrm{T}_{5}(20$ days and $97.13 \%)$ which might be due to increased availability of bio-stimulants or growth promoting substances like phytohormones and vitamins in the presence of Azotobacter (Bhattacharya et al., 2000, Kumar et al., 2001. Lone et al. (2015) had also confirmed better emergence of potato plants under application of biofertilizers .
Table 2 : Yield related attributes of potato after different treatment schedule of biofertilizers

\begin{tabular}{llllll}
\hline Treatments & \multicolumn{2}{c}{ Yield $\left(\mathrm{kg} \mathrm{plot}^{-1}\right)$} & & \multicolumn{2}{c}{ Yield $\left(\mathrm{t} \mathrm{ha}^{-1}\right)$} \\
\cline { 2 - 3 } \cline { 5 - 6 } & $\begin{array}{l}\text { Fresh } \\
\text { yield }\end{array}$ & $\begin{array}{l}\text { Marketable } \\
\text { yield }\end{array}$ & & $\begin{array}{l}\text { Fresh } \\
\text { yield }\end{array}$ & $\begin{array}{l}\text { Marketable } \\
\text { yield }\end{array}$ \\
\hline $\mathrm{T}_{1}$ & 37.93 & 34.14 & & 18.21 & 16.39 \\
$\mathrm{~T}_{2}$ & 51.75 & 47.92 & & 24.84 & 23.00 \\
$\mathrm{~T}_{3}$ & 43.96 & 40.90 & & 21.10 & 19.63 \\
$\mathrm{~T}_{4}$ & 42.65 & 39.96 & & 20.47 & 19.18 \\
$\mathrm{~T}_{5}$ & 57.71 & 53.23 & & 27.70 & 25.55 \\
$\mathrm{~T}_{6}$ & 67.38 & 62.95 & 32.34 & 30.21 \\
$\mathrm{~T}_{7}$ & 51.78 & 48.09 & 24.85 & 23.08 \\
$\mathrm{~T}_{8}$ & 68.85 & 63.82 & 33.05 & 30.63 \\
Mean & 48.88 & 52.75 & 25.32 & 23.46 \\
$\mathrm{CD}$ at 5\% & 9.58 & 10.97 & 5.26 & 4.60 \\
SEm \pm & 29.91 & 39.22 & & 8.47 & 6.89 \\
CV & 11.19 & 11.87 & 11.87 & 11.19 \\
\hline
\end{tabular}

The observations from Table 1 and Fig. 2, clearly reflected non-significant effect of biofertilizer application on the plant height, however the highest $(78.21 \%$ and $181.31 \%)$ growth was reported to be in $\mathrm{T}_{8}$ (50\% of RDF + PSB + Azotobacter + $\mathrm{VAM}+$ Mustard cake) at 45 and 60 days of emergence, respectively. Similarly, the highest $(3.666,5.466$ and 6.333 , respectively) number of branches (Table 1) were recorded in $T_{6}$ ( $50 \%$ of RDF + PSB + VAM + Azotobacter) at 30,45 and 60 days of emergence followed by $T_{7}$ (3.533) at 30 day sand $T_{8}(5.033$ and $6.166)$ at 45 and 60 days of emergence, respectively. The presence of VAM fungi might be responsible for providing resistance against the low temperature, disease and pest attack so maintaining the vegetative growth at later phase. The present finding is in conformity with Yao et al. (2002) in micro propagated Gold rush and LP89221 cultivars of potato. Dash and Jena (2015) had also confirmed the growth promoting attributes of Azotobacterand PSB combination in potato.

The continuous nutrient supply by slow releasing biofertilizers like PSB, VAM and Azotobacter ensured efficient nitrogen utilization by potato plants subsequently, higher vegetative growth (Table 1 and Fig. 2) which might have maximized Leaf Area Index under different treatments like 7.06 in $\mathrm{T}_{6}\left(50 \%\right.$ of RDF + PSB + VAM + Azotobacter) followed by 7.04 in $\mathrm{T}_{8}$

Table 3 : Economic analysis of potato cultivation after different treatment schedule of biofertilizers

\begin{tabular}{|c|c|c|c|c|c|c|}
\hline \multirow[t]{2}{*}{ Treatments } & \multicolumn{3}{|c|}{ Cost of Inputs (Rs) } & \multirow{2}{*}{$\begin{array}{l}\text { Gross Income } \\
\text { (Rs) }\end{array}$} & \multirow{2}{*}{$\begin{array}{l}\text { Net Income } \\
\text { (Rs) }\end{array}$} & \multirow[t]{2}{*}{$\mathrm{B}: \mathrm{C}$ ratio } \\
\hline & Nutrient inputs & Other inputs & Total cost & & & \\
\hline $\mathrm{T}_{1}$ & 14382.5 & 52000 & 66382.5 & 147510 & 81127.5 & 1.222: 1 \\
\hline $\mathrm{T}_{2}$ & 45691.25 & 52000 & 97691.25 & 207000 & 109308.8 & 1.119: 1 \\
\hline $\mathrm{T}_{3}$ & 31191.25 & 52000 & 83191.25 & 176670 & 93478.75 & 1.124: 1 \\
\hline $\mathrm{T}_{4}$ & 26191.25 & 52000 & 78191.25 & 172620 & 94428.75 & 1.208: 1 \\
\hline $\mathrm{T}_{5}$ & 58191.25 & 52000 & 110191.25 & 229950 & 119758.8 & 1.087: 1 \\
\hline $\mathrm{T}_{6}$ & 53191.25 & 52000 & 105191.25 & 271890 & 166698.8 & 1.585: 1 \\
\hline $\mathrm{T}_{7}$ & 38691.25 & 52000 & 90691.25 & 207720 & 117028.8 & 1.290: 1 \\
\hline $\mathrm{T}_{8}$ & 65691.25 & 52000 & 117691.25 & 275670 & 157978.8 & 1.342: 1 \\
\hline
\end{tabular}




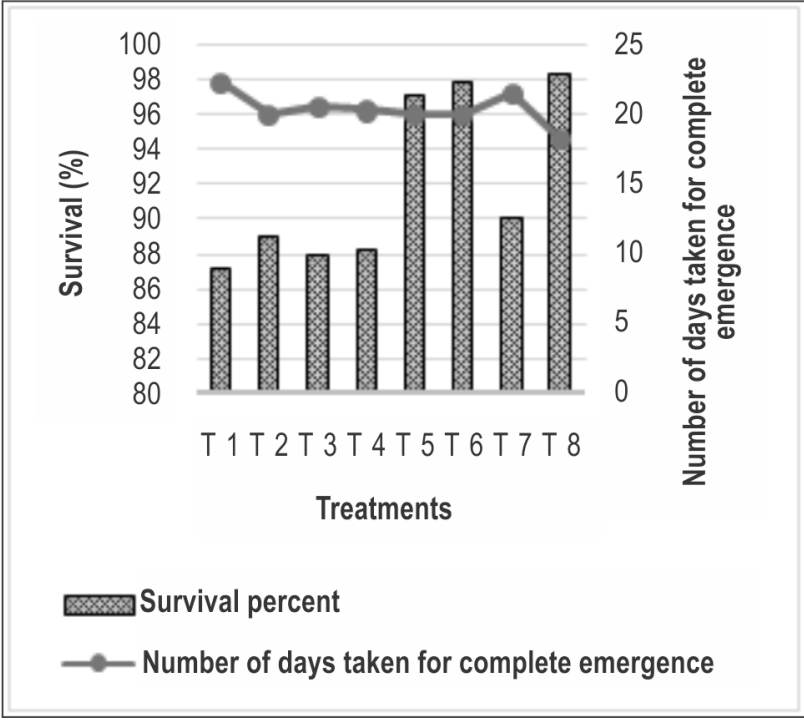

Fig. 1 : Variation in emergence and survival of potato plants under different treatment schedule of biofertilizers.

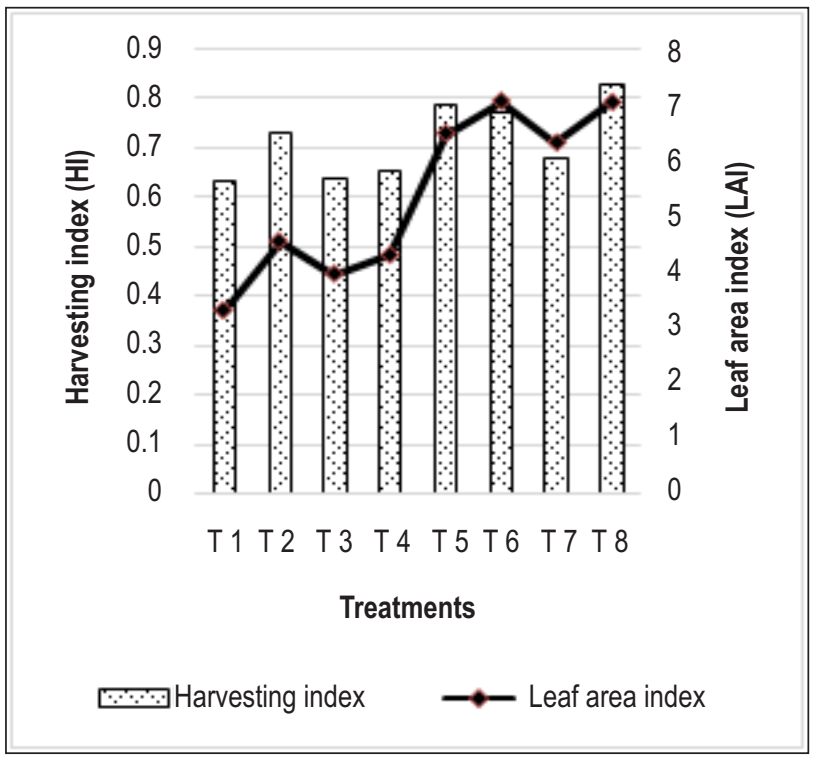

Fig. 3 : Variation in Leaf Area Index and Harvesting Index of potato plants under different treatment schedule of biofertilizers.

( $50 \%$ of RDF + PSB + Azotobacter+ VAM + Mustard cake) and 6.31 in $\mathrm{T}_{7}(50 \%$ of RDF $+\mathrm{PSB}+$ Azotobacter+ Mustard cake)(Fig. 3). The present result can be confirmed by findings of Yin et al. (2000 and 2003), Najm et al. (2010) and Dash and Jena (2015). The observations recorded on harvesting index $(\mathrm{HI})$ of potato plant (Fig.3) confirm highest (0.828) harvesting index in $\mathrm{T}_{8}$ $(50 \%$ of RDF + PSB + Azotobacter + VAM + Mustard cake $)$ followed by $T_{5}(0.787)$ and $T_{6}(0.775)$ which could be due to greater distribution of dry matter in tubers at maturityas reported by Mazurczyk et. al. (2009) and can be confirmed by findings of Narayan et al. (2013) who had reported significantly superior

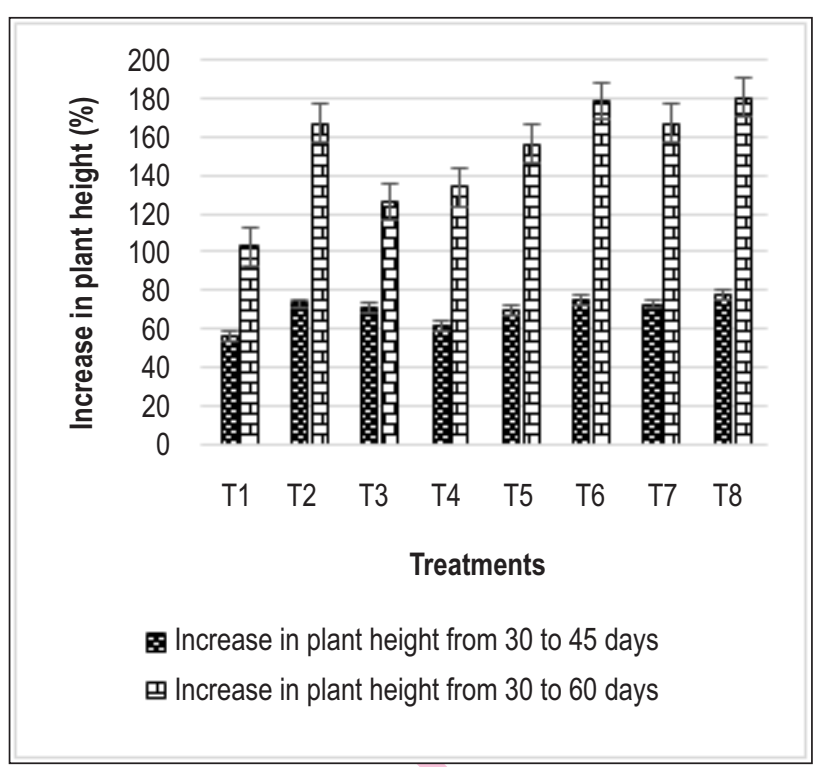

Fig. 2 : Variation in growth of potato plants measured from 30 to 45 and 60 days of tuber planting under different treatment schedule of biofertilizers.

harvest index in potato when $75 \%$ of RDF was combined with $8 \mathrm{t}$ ha ${ }^{-1} V$ ermicompost and tubers were treated with Azotobacter and PSB.

The data presented in Table 2 reflects the highest fresh yield ( $68.85 \mathrm{~kg} \mathrm{plot}^{-1}$ and $33.05 \mathrm{t} \mathrm{ha}^{-1}$ ) and marketable yield (63.82 $\mathrm{kg} \mathrm{plot}^{-1}$ and 30.63 tha $\left.^{-1}\right)$ in $\mathrm{T}_{8}$ (50\% of RDF + PSB+ Azotobacter+ $\mathrm{VAM}+$ Mustard cake) followed by $\mathrm{T}_{6}$ for fresh yield $\left(67.38 \mathrm{~kg} \mathrm{plot}^{-1}\right.$ and $\left.32.34 \mathrm{t} \mathrm{ha}^{-1}\right)$ as well as marketable yield (62.95 $\mathrm{kg} \mathrm{plot}^{-1}$ and $\left.30.21 \mathrm{tha}^{-1}\right)$. All the treatments where biofertilizers were supplied showed significantly better yield in comparison to plants fertilized with $100 \%$ of NPK from inorganic sources $\left(T_{1}\right)$ which could be attributed with efficient utilization of nutrients to promote high photosynthetic rate, formation of medium size tubers and increase in production of dry matter in tuber as reported by Dash and Jena (2015); Nandekar et al. (2006); Zargar et al. (2008) and Farag Jr. et al. (2013) during their investigations. Mukhongo et al. (2017) reported highest yield in sweet potato due to application of biofertilizers in combination with inorganic fertilizers.

The economic analysis constitutes calculation of inputs cost, gross income, net income and Benefit: Cost ratio (Table 3). The highest per hectare cost of cultivation (Rs. 117691.25) was reported in $T_{8}$ followed by $T_{5}$ (Rs. 110191.25) and $T_{6}$ (Rs. 105191.25) while the lowest cost of cultivation (Rs. 66382.50) was reported in $T_{1}(100 \%$ of NPK through inorganic fertilizers) which could be due to cost intensive nature of biofertilizers (Azotobacter, VAM or PSB) or mustard cake as confirmed by findings of Singh and Singh (2015) in vermicompost based intercropping of Amorphophallous in guava. 
The highest (Rs. 275670.00 ha $^{-1}$ ) gross income was reported in $\mathrm{T}_{8}$ ( $50 \%$ of RDF + PSB+ Azotobacter+ VAM + Mustard cake) followed by $\mathrm{T}_{6}$ (Rs. 271890.00 ha $^{-1}$ ) while the highest (Rs. 166698.80 ha $^{-1}$ ) net income was reported in $T_{6}$ followed by $T_{8}$ (Rs 157978.80 ha $^{-1}$ ) whereas lowest gross and net income (Rs. 147510.00 ha $^{-1}$ and Rs. 81127.50 ha $^{-1}$, respectively) was reported in $T_{1}(100 \%$ of RDF). Similarly, the highest $(1.585: 1) \mathrm{B}$ : C ratio was estimated in $\mathrm{T}_{6}$ (50\% of RDF + PSB+ VAM + Azotobacter) followed by $T_{8}(1.342: 1)$ and $T_{7}(1.290: 1)$ in comparison to $T_{1}$ (1.222:1). The high marketable yield is accountable to higher income and $\mathrm{B}: \mathrm{C}$ ratio in biofertilizers based potato cultivation. Dash and Jena (2015) had reported maximum gross income and net income due to application of Azotobacter and PSB with 25\% lesser dose of nitrogen and phosphorous while, Narayan et al. (2013) had proposed high B:C ratio (1.75) in potato cultivated with $75 \%$ of RDF +8 tonnes ha ${ }^{-1}$ Vermicompost and pre-sowing tuber treatment with Azotobacterand PSB.

Application of biofertilizers like PSB, VAM and Azotobacter improves survival, vegetative growth, $\mathrm{LAI}, \mathrm{HI}$ and tuber yield in potato due to efficient nutrient utilization and release of growth promoting substances. The biofertilizers can be used to replace of $50 \%$ of RDF without loss in profitability of potato cultivation. Among different treatments, $\mathrm{T}_{8}(50 \%$ of RDF $+\mathrm{PSB}+$ Azotobacter+ VAM+ Mustard cake) and $\mathrm{T}_{6}(50 \%$ of RDF + PSB+ $\mathrm{VAM}+$ Azotobacter) have been reported to be economically feasible for biofertilizer based potato cultivation in Central Plain Zone $(\mathrm{Pb}-3)$ of Punjab.

\section{Acknowledgment}

The authors would like to give their sincere thanks to Lovely Professional University, Punjab, India for the professional and financial support.

\section{References}

Almodares, A., R. Taheri, M. Chung and M. Fathi: The effect of nitrogen and potassium fertilizers on growth parameters and carbohydrate contents of sweet sorghum cultivars. J. Environ. Biol., 29, 849-52 (2008).

Bhattacharya, P., R.K. Jain and M.K. Paliwal: Biofertilizers for vegetables. Indian Horticulture, 45, 12-13 (2000).

Dash, S.N. and R.C. Jena: Biofertilizer options in nutrient management of potato. Int. J. Sci. Res., 4, 420-421 (2015).

deAraújo, A.S., J.R. Oliveira, R.M. Araújo and R.L. Gomes : Biofertilizers on soil microbial biomass and activity. Brazilian J. Agri. Sci./Revista Brasileira de CiênciasAgrárias, 9, 545-549 (2014).

Farag Jr, M.I., M.A. Abdalla, M.F. Mohamed and M.H. Aboul-Nasr : Effect of bio fertilization on yield and quality of some potato cultivars (Solanum tuberosum L.). Int. J. Agricul. Food Sci. Technol., 4, 695$702(2013)$

Kumar, V., R.C. Jaiswal and A.P. Singh: Effect of biofertilizers on growth and yield of potato. J. Indian Potato Assoc., 28, 60-61 (2001).

Lemoine, R., S. La Camera, R.Atanassova, F. Dédaldéchamp, T. Allario, N. Pourtau and M. Faucher : Source-to-sink transport of sugar and regulation by environmental factors. Front. Plant Sci., 4, 272 (2013).
Lone, R., R. Shuab, V. Sharma, V. Kumar, R. Mir and K.K. Koul : Effect of arbuscular mycorrhizal fungi on growth and development of potato (Solanum tuberosum) plant. Asian J. Crop Sci., 7, 233-243 (2015).

Mazurczyk, W., A. Wierzbicka and C. Trawczynski: Harvest index of potato crop grown under different nitrogen and water supply. Acta Scientiarum Polonorum Agricultura, 8, 15-21 (2009).

Mc Gregor, I.: The fresh potato market. In: Potato Biology and Biotechnology (Eds.:D. Vreugdenhil). Elsevier, Amsterdam, pp.336 (2007).

Mirshekari, B. and M.H. Alipour: Potato (Solanum tuberosum) seed biopriming influences tuber yield in new released cultivars. Int. J. Biosc., 3, 26-31 (2013).

Mohammadi, G.R.,A.R. Ajirloo, M.E. Ghobadi and A. Najaphy: Effects of non-chemical and chemical fertilizers on potato (Solanum tuberosum L.) yield and quality. J. Medic. Plants Res., 7, 36-42 (2013).

Mohammadi, K. and Y. Sohrabi : Bacterial biofertilizers for sustainable crop production: A review. ARPN J Agric. Biol. Sci., 7, 307-316 (2012).

Mukhongo, R.W., J.B. Tumuhairwe, P. Ebanyat, A.H. Abdel Gadir, M. Thuita and C. Masso : Combined application of biofertilizers and inorganic nutrients improves sweet potato yields. Frontiers in Plant Science, 8, (2017). DOl: 10.3389/fpls.2017.00219.

Najm, A.A., M.H.S. Hadi, F. Fazeli, M.T. Darzi and R.Shamorady: Effect of utilization of organic and inorganic nitrogen source on the potato shoots dry matter, leaf area index and plant height, during middle stage of growth. World Acad. Sci. Engin. Technol., 47, 900-903 (2010).

Nandekar, D.N., S.D. Sawarkar and A.K. Naidu: Effect of biofertilizers and NPK on growth and yield of potato in Satpura plateau. Potato J., 33, 168-169 (2006).

Narayan, S., R.H. Kanth, R. Narayan, F.A. Khan, P. Singh and S.U. Rehman: Effect of integrated nutrient management practices on yield of potato. Potato J., 40, 84-86 (2013).

National Horticulture Board: Overview of Horticulture Sector. Horticultural Statistics at a glance 2017, Horticulture Statistics Division, Department of Agriculture, Government of India, pp.8-19 (2017).

Singh, S.K. and P.K. Singh: Intercropping elephant foot yam is an economical cultivation practice for Indian goose berry (Phylanthus emblica) orchard management. New Agriculturist, 26, 357-363 (2015).

Van Gijssel, J.: The potential of potatoes for attractive convenience food: Focus on product quality and nutritional value. Potato in Progress Science Meets Practices. Wageningen Academic Publishers, Wageningen, The Netherlands, pp. 27-32 (2005).

Yao, M., R. Tweddell and H. Desilets: Effect of two vesicular-arbuscular mycorrhizal fungi on the growth of micropropagated potato plantlets and on the extent of disease caused by Rhizoctonia solani. Mycorrhiza, 12, 235-242 (2002).

Yin, X., A.H. Schapendonk, M.J. Kropff, M. van Oijen and P.S. Bindraban: A generic equation for nitrogen-limited leaf area index and its application in crop growth models for predicting leaf senescence. Annals of Botany, 85, 579-585 (2000).

Yin, X., E.A. Lantinga, A.H. Schapendonk and X. Zhong: Some quantitative relationships between leaf area index and canopy nitrogen content and distribution. Annals of Botany, 91, 893-903 (2003).

Zargar, M.Y., Z.A. Baba and P.A. Sofi: Effect of N, P and biofertilisers on yield and physico-chemical attributes of strawberry (Fragaria annanosa D.). J. Plant Nutri., 6, 3-8 (2008). 